динамического наблюдения у пациентов с СД и атеросклерозом.

4.Пациенты сэректильной дисфункцией, особенно в молодом возрасте, должны проходить тщательное всестороннее обследование эндокринной и сердечно-сосудистой систем, включая дуплексное сканирование сосудов, с целью раннего выявления субклинических форм СД и атеросклеротических изменений периферических артерий.

5. Пациентам с ранними атеросклеротическими изменениями перифери-ческих артерий необходимо обследование и динамическое наблюдение эндокринолога с целью раннего выявления или исключения сахарного диабета.

6. Раннее выявление субклинических изменений сосудистой стенки, модификация образа жизни, адекватное и агрессивное лечение факторов риска сахарного диабета и атеросклероза, грамотное и своевременное назначение фармакотерапии (включая статины и ангиопротекторы) самый действенный способ снизить уровень риска фатальных и нефатальных сердечнососудистых осложнений, достигнуть увеличения продолжительности и улучшения качества жизни у пациентов с сахарным диабетом 2 типа.

\section{ЛИТЕРАТУРА}

1. Куликова А.Н. Облитерирующий атеросклероз артерий нижних конечностей на фоне сахарного диабета II типа (этиопатогенез, клиника, диагностика, хирургическое и медикаментозное лечение, профилактика): автореф. дисс. докт. мед. наук: спец. 14.00.27 «хирургия» / Куликова Алла Николаевна; Саратовский государственный медицинский университет. - Саратов, 2009.

2. Прибила О.В. Облитерирующий атеросклероз артерий нижних конечностей - неоцененная опасность при сахарном диабете / O.В. Прибила, О.В. Зинич, Г.А. Мелуа // Український медичний часопис. - 2018. - Т. 2, №2(124). - С.1-4.

3. Сахарный диабет и атеросклероз: эпигенетические механизмы патогенеза. Обзор литературы / Л.К. Соколова, В.М. Пушкарев, Е.И. Ковзун, В.В. Пушкарев, Н.Д. Тронько // Український кардіологічний журнал. - 2017. №6. - С. 104-117.

Дата надходження до редакції 19.10.2018 p.

https://doi.org/10.24026/1818-1384.4(64).2018.150172

\title{
СТРАТЕГІЇ ЛІКУВАННЯ ПАПІЛЯРНИХ ТИРЕОЇДНИХ КАРЦИНОМ ЧЕРЕЗ 32 РОКИ ПІСЛЯ АВАРІЇ НА ЧОРНОБИЛЬСЬКІЙ АЕС
}

\author{
А.С. Коваленко, Ю.М. Таращенко, Б.Б. Гуда, М.Д. Мельник, \\ М.В. Остафійчук \\ ДУ «Інститут ендокринологї та обміну речовин ім. В.П. Комісаренка НАМН України»
}

Ризик розвитку карцином щитоподібної залози у постраждалих у дитячому віці в результаті аварії на ЧАЕС осіб буде зберігатися ще тривалий час. Проведення постійного тиреоїдного скринінгу цієї групи дозволить виявити захворювання на ранніх стадіях розвитку. Основними ключовими питаннями в лікуванні тиреоїдних карцином залишаються: точність доопераційної цитоморфологічної діагностики, стратифікація ризику та агресивність лікування.

Мета: Оцінити результати лікування й визначити оптимальний протокол діагностики, терапії та моніторингу пацієнтів з папілярними тиреоїдними карциномами.
Матеріал та методи. Проведений аналіз лікування 5830 пацієнтів 3 папілярним раком щитоподібної залози за період з 1990 по 2015 роки. Термін спостереження становив від 1 до 25 років після первинної операції, в середньому 11,8 2,1 року. Вік хворих варіював від 7 до 74 років. Середній вік становив $38,3 \pm 7,4$ року. Пацієнтів жіночої статі було 4706 (80,7\%), чоловічої - 1124 (19,3\%).

Результати та обговорення. Папілярні тиреоїдні карциноми раннього післяаварійного періоду характеризувалися коротким попереднім періодом розвитку, високим біологічним потенціалом злоякісності 3 високим рівнем інвазивності (екстратиреоїдна інвазія - 51,7\%, реґіонарне 
лімфогенне метастазування - 36,7\%, віддалене метастазування в легені - 5,2\%). 3 часом підвищення якості ультразвукової і цитологічної діагностики дозволило збільшити кількість операцій, які проведені на ранніх стадіях розвитку карцином - до 59,8\% спостережень. В терапевтичному протоколі була використана тактика рестратифікації ризику на етапах лікування, з визначенням обсягу хірургічного втручання, характеру терапії радіоактивним йодом і супресивної терапії левотироксином.

Проведено 5267 (90,3\%) тиреоїдектомій, 563 (9,7\%) лобектомій при мінімально-інвазивній папілярній карциномі, 1633 (29\%) дисекцій шиї різного обсягу. При локально-інвазивних пухлинах виконувались операції 3 резекцією органів аеродигестивного тракту. В більшості випадків при розповсюджених формах захворювання виконання тиреоїдектомії 3 дисекцією центрального та, при необхідності, бокових відсіків шиї 3 подальшою аблацією радіоактивним йодом дозволило знизити кількість рецидивів в 2,5 рази. Рецидивні та резидуальні йодрезистентні метастази призвели до повторних операцій. Виконання профілактичної дисекції центрального відсіку шиї дозволило покращити

Дата надходження до редакції 09.10.2018р. діагностику мікрометастазів, досягти зниження рівня передаблаційного тиреоглобуліну та знизити променевенавантаженняпритерапіїl131.Виконання лобектомії при мінімально-інвазивній папілярній карциномі категорії Т1 $\epsilon$ досить радикальним втручанням і не збільшує ризик розвитку рецидиву. Застосування диференційованого лікувального підходу дозволило досягти сприятливих результатів лікування. Безрецидивна виживаність протягом 5 років становила 95,7\%, 10 років - 92,5\% і 15 років - 79,4\%. Кумулятивне п'ятирічне виживання за методом Каплан-Мейер становило 99,1\%, десятирічне - 98,9\%, п'ятнадцятирічне - 98,9\%.

Висновки. Стратегії лікування папілярних тиреоїдних карцином у населення України мають носити персоніфікований характер. В більшості випадків залишається виправданим радикальний протокол лікування, який оснований на виконанні тиреоїдектомії 3 дисекцією шиї та аблаційною терапією 1131. В групі низького ризику при мінімально-інвазивній папілярній карциномі можливе виконання гемітиреоїдектомії з наступною супресивною терапією левотироксином.

\title{
ІНФАРКТ МІОКАРДУ ТА ІНСУЛЬТ У ХВОРИХ НА ЦУКРОВИЙ ДІАБЕТ 2 ТИПУ: ЕПІДЕМІОЛОГІЧНІ ТА СОЦІАЛЬНО-ЕКОНОМІЧНІ АСПЕКТИ
}

\author{
3.Г. Крушинська \\ Украйнський науково-практичний иентр ендокринної хірургії, трансплантації \\ ендокринних органів і тканин МОЗ України
}

Мета: Вивчити епідеміологічні та соціальноекономічні особливості інфаркту міокарду (IM) та інсульту у хворих на цукровий діабет (ЦД) 2 типу.

Матеріали та методи. Пацієнти були розподілені на 3 групи: до першої групи увійшли всі хворі на ЦД, які взяли участь у дослідженні ( $n=1999)$, до другої групи - хворі на ЦД з першої групи з IM $(n=201)$, до третьої групи - хворі на ЦД з першої групи з інсультом ( $n=155)$. Кожна група також була розподілена з урахуванням статі хворого.

Особливості перебігу IM та інсульту у хворих на ЦД (вік, стать, соціальний статус, місце проживання, тривалість захворювання, рівень глікованого гемоглобіну, частота ускладнень та супутньої патології, наявність ожиріння, схеми лікування) i взаємозв'язок між ними вивчалися з використанням порівняльного аналізу отриманих даних.

Результати. У першій групі частка хворих обох статей практично не відрізняється, у другій групі більшість становлять чоловіки (55,7\%), у третій групі - жінки (58,1\%). Аналогічна ситуація спостерігається також при дослідженні частоти IM та інсульту у хворих на ЦД в залежності від статі пацієнта: серед хворих на ЦД з ІМ переважають чоловіки (10,9 проти 